\title{
Public Trust and Regulatory Compliance ${ }^{1}$
}

\author{
Ambar Widaningrum²
}

\begin{abstract}
Several studies have proven that public trust in government improves the level of policy or regulation acceptance and reduce administrative costs. In contexts where trust in government is high, citizens tend to be more willing to voluntarily comply with public policies. This article aims to explore issues of trust and distrust toward government, seen from the aspect of public compliance, both to rules or policies. The level of public trust toward government is expressed by giving its support through its conduct which complies with the existing rules. This study employed a case study research design, which was conducted in Yogyakarta, July 2015 - March 2016. It assessed the government regulation on Traffic and Road Transport and Local Regulation on Street Vendors Management. This study concludes that a number of non-compliant behaviors is a form of low public trust in government. Disobedience is a representation of government failure to enforce the rule of law which resulted in some of the processes and procedures of public services that have not been followed by people. Level of public trust in the government regulation is an output of a variety of interrelated elements: the performance of the implemented regulation to solve public problems; consistency in the regulation's enforcement and fairness, and government officials' behavior, demonstrated through exemplary attitude.
\end{abstract}

\section{Keywords:}

public trust; compliance; governance of public services.

\begin{abstract}
Abstrak
Beberapa studi telah membuktikan bahwa kepercayaan publik terhadap pemerintah meningkatkan tingkat penerimaan publik terhadap kebijakan atau peraturan yang dikeluarkan oleh pemerintah, sekaligus juga mengurangi biaya administrasi yang ditimbukkan dari kebijakan tersebut. Pada konteks dimana kepercayaan pada pemerintah tinggi, warga cenderung mematuhi kebijakan publik secara sukarela. Artikel ini bertujuan untuk menggali isu-isu kepercayaan dan ketidakpercayaan publik terhadap pemerintah, dilihat dari aspek kepatuhan masyarakat terhadap peraturan atau kebijakan. Tinggi dan rendahnya kepercayaan publik dinyatakan dalam dukungan publik melalui perilaku patuh terhadap peraturan-peraturan yang dikeluarkan oleh pemerintah. Desain penelitian ini adalah studi kasus, yang dilakukan pada kurun waktu Juli 2015- Maret 2016 di Yogyakarta. Kebijakan atau peraturan pemerintah yang diteliti adalah: 1). Undang-undang Lalu Lintas dan Angkutan Jalan; 2). Peraturan Daerah tentang pengelolaan Pedagang Kaki Lima (PKL). Studi ini menyimpulkan bahwa jumlah pelanggaran publik atau perilaku yang tidak sesuai merupakan cerminan rendahnya kepercayaan publik terhadap pemerintah. Ketidaktaatan adalah representasi dari kegagalan pemerintah untuk mewujudkan rule of law, yang menjadi alasan terjadinya pelanggaran oleh masyarakat, baik pada proses maupun prosedur

\footnotetext{
1 This article is a revised draft of a paper presented in the Korean Association for Policy Studies (KAPS) Autum International Conference, Seoul, September 23, 2016.

2 Department of Public Policy and Management, Faculty of Social \& Political Sciences, Universitas Gadjah Mada Email: ambarwidaningrum@gmail.com
} 
pelayanan publik. Tingkat kepercayaan publik terhadap peraturan pemerintah merupakan keluaran dari berbagai elemen yang saling terkait: kinerja kebijakan dalam memecahkan masalah publik; konsistensi dalam melakukan penegakan peraturan dan keadilan, dan; penilaian publik terhadap perilaku pejabat pemerintah, yang ditunjukkan melalui keteladanannya.

\section{Kata kunci:}

kepercayaan publik; kepatuhan; tata kelola pelayanan publik.

\section{Introduction}

The2017 Edelman Trust Barometer Survey shows the largest-ever drop in trust across the institutions of government, business, media and NGOs. Among the general population, the trust deficit is even more pronounced, with nearly two-thirds of countries falling into the distruster category. Trust in media (43 percent) fell swiftly and is at an all-time low in 17 countries, while trust levels in government (41 percent) dropped in 14 markets and is the least trusted institution in half of the 28 countries surveyed. The credibility of leaders is also in danger: CEO credibility dropped 12 points globally to an all-time low of 37 percent, falling in every country studied, while government leaders ( 29 percent) remain the least credible. The cycle of distrust is amplified by the emergence of a media echo chamber that reinforces personal beliefs while shutting out opposing points of view. Respondents favor search engines ( 59 percent) over human editors (41 percent) and are nearly four times more likely to ignore information that supports a position they do not believe in (the Edelman, 2017).

Fortunately, according to that survey, Indonesians have the second highest trust level on four crucial institutions - government, business or corporations, media and nongovernment organizations (India and China respectively at the first and the third highest trust level). The average trust level in institutions increased 7 percent (62 percent in 2016 to 69 percent in 2017) while trust in government increased 13 percent this year. This increased level in Indonesia is unique in the midst of a crisis of trust that has hit other countries in the world. It shows that the model applied by the Indonesian government to close the gap between the elite and the public and provide equitable revenue opportunities and social infrastructure, has been well received. Another interesting finding from the survey is that trust in social media in Indonesia has dropped to its lowest level ever, while trust in mainstream media and official corporate or individual social-media accounts have gone up (see Table 1).

Trust allows the government to implement policies without difficulty. In contexts where trust in government is high, citizens tend to be more willing to voluntarily comply with public policies (Im, Cho, Porumbescu, \& Park, 2014). Conversely, in contexts where trust in government is low, the costs of policy implementation tend to be higher (Scholz \& Lubell, 1998). Citizens believe that the government is capable of carrying out its role as the manager of government activity. Therefore, public trust describes a condition in which people have confidence in the competence of the government in performing its role as the manager of government activity. It is becoming more and more important as major social capital. Furthermore, public trust is also very important in encouraging people to participate in governance and citizenship activities. When people have a high public trust in government, the community involvement in civic activities will be higher.

Although the level of trust towards the government in Indonesia is quite encouraging, the government is still facing many challenges 
Table 1.

Trust Level in Indonesia

\section{Trust in All Four Institutions Increases}

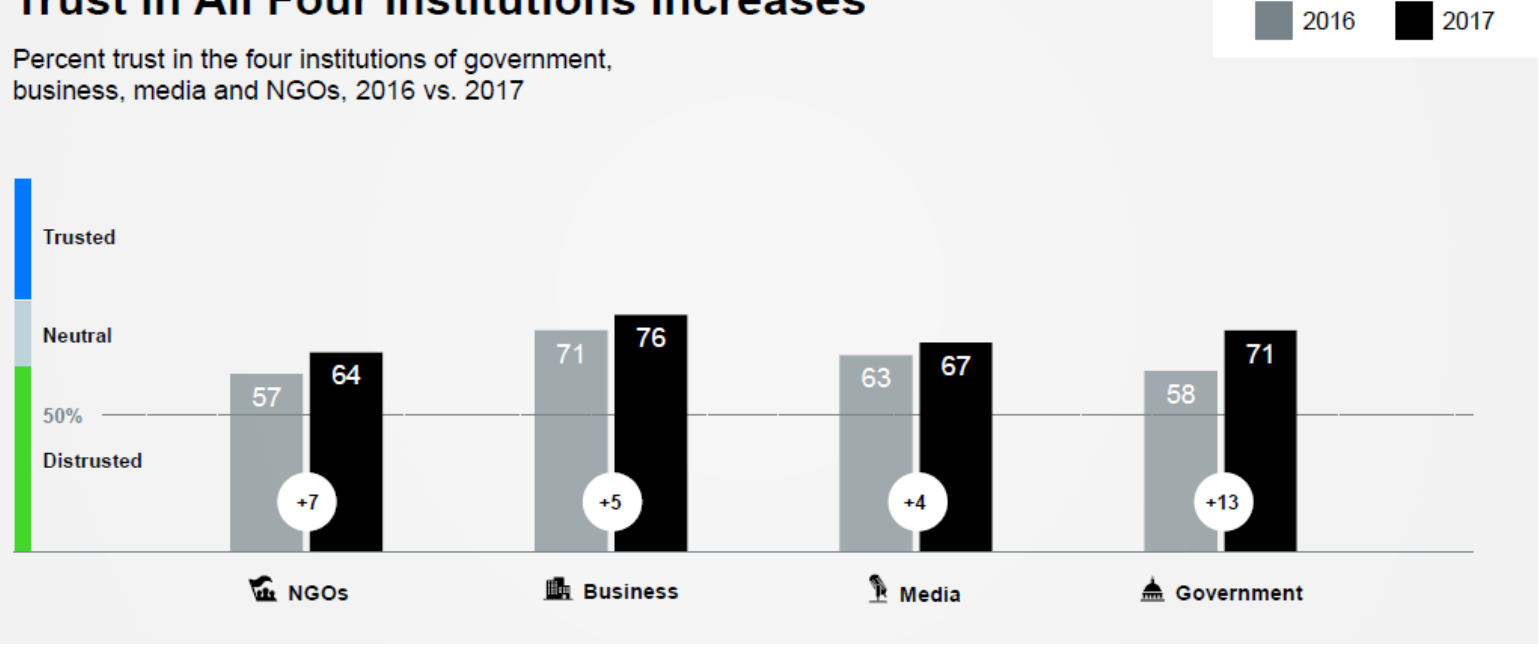

Sources: The 2017 Edelman Trust Barometer: Global and Indonesia

to win public trust. This article describes the result of a preliminary study that aims to explore issues of trust and distrust towards government, and is seen from the aspect of rules enforcement, particularly rules related to regulatory compliance. The proposition used for this study is: "The higher level of public confidence to follow government policy, the higher public trust in government." This assumption underlines the importance of public trust in democratic governance. Thus, the main question is: "Why is rules enforcement often not followed by some people?" The result of research which has been conducted in Yogyakarta Province, Indonesia at the end of 2015 provides a clear picture of problems associated with the performance of government policies or programs implementation primarily on regulatory policy or policies that regulate the behavior of the people. Recommendations from this study are expected to reinforce the importance of public trust in the government policy implementation.

\section{Literature Review}

Trust is a theme which has attracted more attention in recent years. Comparison of general level of trust in the government in various countries starting from a philosophical discussion about the need for trust in government. Trust refers to a high estimation of the competence, honesty, or reliability of the one who is trusted, according to the expectations or norms of the beholder (Kleinnijenhuis, van Hoof, and Dirk Oegema, 2006). Public trust is not constant in any given culture (Boukaert and de Walle, 2003). It is a subjective phenomenon, even emotional. By contrast, the nature of trust in government is always changing. Nixon (2007) also mentioned that trust has meaning, implications and different outcomes depending on the conditions, institutional settings, and actors involved. Public management theories tend to explain the absence of public trust in government as a representation of the poor performance of the government system, therefore, public trust can be restored by improving the quality of public services. Furthermore, Christense \& Laegreid (2013) also explained that people who have had positive experiences related to services provided by government institutions will have a high trust in those institutions. Simply stated, the concept of public trust is complex, and given 
the socioeconomic and political context, is very dynamic over time.

Most research focuses on Western Europe believes that public trust is indispensable because it indicates the level of government performance, good or bad (Boukaert and de Walle, 2003). However, a high level of trust and satisfaction does not always reflect what is commonly called 'good governance'. Castillo, et.al (2011) explained that trust is the basis for building a relationship between individuals, groups or institutions. In the context of democratic life, public trust in public institutions is very important. Institutions that receive high trust from the people have strong legitimacy in carrying out their duties, and people are more willing to engage in any activities organized by those institutions. See Beh (2013) defined trust in government as the reciprocity of expectations where the citizens expect that the government will perform in the interest of the citizens as they were promised. Within this perspective, the decline of trust of the government would be due to the government's failure to live up to the expectations of its citizens based on its promises to them. Trust in government is essentially related to administrative integrity and service performance.

The hypothesis presented by some scholars about public trust is, the higher the trust and public satisfaction with government performance, the better the governance system (Boukaert and de Walle, 2003; Christense \& Laegreid, 2013; See Beh, 2013). An improving quality of governance will increase the public trust, so that the public increasingly rely on and are satisfied with the government. OECD (2013) explains that public service is a public trust. People expect public servants to serve public interest fairly and to manage public resources properly on a daily basis. Fair and reliable public services inspire public trust and create a favorable environment for businesses, thus contributing to well-functioning markets and economic growth. Therefore, citizen satisfaction with public services could be one of the entrances to building public trust.

\section{Dimensions of Public Trust}

The existence of public trust has implications on several aspects (Fukuyama, 1995; Bouckaert \& de Walle, 2003; Dwiyanto, 2011). First, trust is an efficient means for lowering transaction costs in any social, economic and political relationship. If people have high trust in the government, the public policy making process will be simpler and faster. The government does not need to undergo a long and tiring negotiation to convince people about the purpose of policy objectives. Second, trust in the government may encourage people to respect the authority of public officials so that the formulation process of government policies and activities becomes easier to do, without any activities to explain, to reassure and to justify the decisions taken. It can also avoid the emergence of distorted understanding of the policy substance which is often a source of problems in the implementation of government policy. Third, public trust can improve the relationship between government and people. When the relationship between government and people are closer, it will show mutual respect between each other, to reduce or eliminate the suspicion between people and the government in policy implementation.

Trust in government depends largely on the intensity of interaction as well as the quality of the relationship between the government and its citizens, since trust in government includes aspects of cognition, affection, and behavior of its government. Blind (2006) distinguishes the concept of trust into two types: political trust and social trust. Political trust happens when citizens appraise the government and its institutions, policy-making in general and/ or the individual political leaders as promisekeeping, efficient, fair and honest. Political trust 
can be directed towards the political system and its organizations as well as the individual political incumbents. Both organizational and individual political trust depends on credible policy-making. Credibility can be defined as an unquestioned criterion of a good policy. Credibility, in general, is assessed in terms of the different perceptions of performance associated with different policies. Good public trust in the organization, as well as individuals, is highly dependent on a credible policymaking process (Bouckaert \& de Walle, 2003; Blind, 2006; OECD, 2013). Specifically, OECD (2013) called integrity. Integrity has become a fundamental condition for the government to provide a credible manner and effectively to the economic and social life of the people. Ensuring integrity means that the behavior of civil servants is in line with the public interest. They run public services reliably and citizens receive services based on legality and justice. When the government utilize and use public resources (including budgets) effectively, efficiently and correctly; and decision-making procedures proceed transparently, then public trust will grow by itself. Easily stated, integrity has been a major prerequisite for the government and its officials to win public trust.

Many scholars in social science and public administration have used "credible commitment" to explain the level of public confidence in the government and its officials (Fukuyama, 1995; Kim, 2005). There are several explanations that are usually used to describe a credible commitment. Kim (2005) describes credible commitment as "encapsulated interest of the government actor to honor her agreement or to act according to a certain standard". A credible commitment has two elements, namely "encapsulated interest" and consistency. The government is considered to have a credible commitment if citizens believe that there is an "encapsulated interest" between themselves and the actors in government institutions. Citizens believe that the actions of the government and its officials are always based on the desire to realize common good and or protect citizen interests and property. The second element of a credible commitment is the consistency of the actions of the government and its officials. When citizens perceive governments and officials as consistent in taking action when facing certain problems, and actions always reflect their concern for their interests, then they are likely to judge that the government and its officials are committed to the interests of its citizens.

Government capacity or competence is an important dimension to strengthen public trust. Public trust always reflects the citizens' assessment of the capacity of government, government agencies and their officials in performing their duties. Performance is the simplest benchmark to win people's trust. Citizens who have high public trust generally are citizens who assess the government, institutions, and officials are able to resolve the problems of its citizens. The performance of the government and its officials in carrying out its functions will greatly affect the perception of citizens about the performance of the government. Several studies and surveys support this hypothesis (Bouckaert \& van de Walle, 2003; the Edelmen, 2017).

Citizen satisfaction is an expression of government performance. The better the government's ability to solve public problems, the higher the level of satisfaction of its citizens. Although satisfaction as an indicator is a subjective indicator, this satisfaction is closely related to public trust (Bouckaert \& de Walle, 2003, OECD, 2013). In this condition, the public's trust to its citizens is becoming higher too.

\section{Methods}

This study adopted a descriptive research design using a case study. The goal of this research design is to develop an in-depth understanding of the problems and issues 
pertaining to implementation of regulatory policy and governance. Case study is an approach to research that facilitates exploration of a phenomenon within its context using a variety of data sources: a) a large variety of factors and relationships are included, b) no basic laws exist to determine which factors and relationships are important, and c) the factors and relationships can be directly observed (Yin, 1994; Yin, 2004; Baxter and Jack, 2008). Since issues of regulatory trust in Indonesia have not been understood very well, an understanding of the nature of the problem affecting regulatory compliance is necessary.

This research was conducted in the Yogyakarta Province, in 2015-2016. The chosen study site is based on identified characteristics: social and cultural characteristics and unique environment which is Yogyakarta, sometimes named as an education city and mini-Indonesia, since many students from many parts of Indonesia are studying in Yogyakarta. The research assessed government policy or regulation as follows: 1). Law on Traffic and Road Transport representing the type of regulatory policy that apply nationally related to all citizens' behavior who use the road and public transport; 2). Local regulations on street vendor management, which represents the type of regulatory policy that manage the vendors' spots/areas, people and street vendors' activities.

Two categories of data were gathered: primary and secondary data. Primary data were collected through interviews and field observations to obtain information. The interviewees were selected from various actors, based on two mechanisms: purposive and snowball selection methods, related to implementation of policy/regulation in order to gain insights from different perspectives. A set of open-ended questions was prepared which aimed to identify any factors affecting the regulatory compliance, policy implementation and to differentiate facilitating from constraining factors. The interviews were focused on two main questions:

1) For officers:

How do the administrative organizations (Regional Police Service, Regional Office of Trade and Cooperatives, Yogyakarta Civil Service Unit) ensure people's compliance with regulation or policies? How do the administrative organizations ensure the evaluation of policies' implementation? This question aims to clarify the context of policy governance and implementation. What are the factors that constrain or facilitate regulatory compliance? Some probing questions were asked depending on informants and interviewees' responses.

2) For citizens (road users \& street vendors):

Based on citizens' experiences, how are the regulations (traffic and/or street vendors' management) implemented? Why is there rule breaking? What are the factors that constrain the citizens from following the rules? Some probing questions were also asked depending on informants and interviewees' responses.

The secondary data collected for this study came from a wide variety of sources, such as internal government documents, government publications, and some research reports about policy implementation of Yogyakarta and its surroundings. Some data from Zahroh's survey (2015) on Government Roles in Traffic Law Enforcement, in which the author involved in the questionnaire development, was utilized as one of the data sources derived from road users. The results of this survey data analysis were then validated with data from observation and interviews with related parties. To increase the trustworthiness, this study followed the analytic process proposed by Baxter and Jack (2008). All the materials were analyzed using triangulation of the data which involved crosschecking multiple data sources and collection procedures to evaluate the extent to which all evidence converges. 


\section{Findings}

\section{Compliance with Law on Traffic and Road Transport}

The number of traffic accidents in Indonesia is still high, including those that happen in Yogyakarta Province. The causes of accidents were varied and one of the main points is breaking the road traffic rules (Yogyakarta Regional Police Services, 2015). In 2015, there were 5,879 incidents of traffic accidents; 128,615 traffic offences; and 70,472 traffic offences by penalties/fines (BPS-Statistics of Yogyakarta Province, 2015). This data is justified by one of the unit heads of Yogyakarta Regional Police Services. He said that the existence of policies might not be sufficient but the enforcement made the difference. Most road traffic accidents were a result of a road user's behavior and more specifically, accidents occurred because of the decisions taken by road users to disobey or break the road rules. Accident rates and rule violations are always related.

Surveys conducted by Zahroh (2015) on the implementation of Law No. 22 of 2009 on Traffic and Road Transport also concluded the same thing. Most respondents who did the offense, agreed and supported the content of the traffic safety rules, but they repeated breaking the rules. There are several reasons underlying their inconsistencies. Not all respondents who committed violations was caused by lack of knowledge about the rules and dangers, but was caused by other factors, such as traffic conditions (congestion), hurriedness, to shorten the travel time, as well as weak and complicated monitoring and management system of sanctions. Multiple responses of the 82 respondents who have offended the road traffic rules show that 43 violations committed by the respondent were due to weak control by authorities. The violations are not solely due to factors related to their interests, but also the factors associated with the habit of breaking the rules. As described by one interviewee:

\begin{abstract}
"Actually, if everyone is obedient, accidents can be reduced a lot... But sometimes the violations that occurred in front of our eyes, left by police officers, are not penalized by the officer, or the offender was released" (CI01, interview dated November 18, 2015).
\end{abstract}

It can also be said that road users are compliant to the rule because it is based on the fear of getting sanctioned. Compliance is interpreted as compliant to the officers. They follow the rules because there are officers who supervise their actions and therefore they follow the rules. This could be due to several reasons. First, law enforcement is not strict and clear, which led to a situation of uncertainty which provides a gap rule for offenders. Second, in some cases, violations were committed by officers (police) or government official vehicles, however there was no clear sanction applied. Both reasons were showing the lack of officers' firmness. A level of control is inversely proportional to the level of violations committed by road users. This further confirms that the level of control (and prosecution) for violations committed by road users influences the high incidence of traffic violations.

In the practice of law enforcement and giving sanction to the traffic violators in which the officer was not assertive and firm, was sometimes associated with the presence of a bribe. Although the information about how to deal with bribery and suspicious behavior has been disseminated and that improper conduct and behavior can be reported through various media, the public perception on bribery as part of daily law enforcement is still strong. As described by one interviewee:

"Public perception of bribes is still definite, despite a lot of good examples of police officers who are orderly, clean and help the road 
users when they get in trouble. But it is still unbreakable...., remove the negative public perception about corruption. It seems to have become a common phenomenon. The government and officers must convince the public continuously. Top officials must also be role models, that bribes cannot be tolerated anymore. Examples of corruption are still often heard."(CI04, interview dated October 14, 2015).

Inferences from road user' interviewees made it clear that the public disobedience against the rules is closely associated with weak law enforcement. Public trust in the traffic rule contents is actually quite high. Their non-compliant behaviors on traffic rules are based on their social learning, such as bad examples from the surrounding environment and unlawful officers' conduct. Despite the efforts to improve the services by establishing a Standard Operation Procedure (SOP), and by providing public service information and a complaints mechanism system, discrepancies in enforcing the rule and bad examples of rules violations, especially those committed by the officers or government official, caused public distrust in government. These findings are also consistent with Diamond (2007) in that corruption and abuse of power represent a betrayal of the public trust. People don't trust government because government is too distant from the people and does not sufficiently solicit and engage their concerns. The core reason for public distrust in government is that government does not deserve to be trusted. It is also stated by Rawlins (2008), that public trust and transparency are important indicators to understand a relationship between government and citizen satisfaction. Corruption, whether it is real or perceived, can lead to public frustration and reduce public trust in public service performance, and then it will reduce public trust in government.

\section{Compliance with the Local Regulation on Street Vendors' Management}

The increasing number of street vendors has had an impact on aesthetics, cleanliness and functioned facilities and infrastructure of urban areas. In some cases, the existence of urban street vendors could even disturb the road traffic. Therefore, it is necessary to manage street vendors. The government has several street vendors management patterns. All of those management patterns are based on several regulations, ranging from the national law to the head region decision (at local level). Street vendor's management conducted by the local government of Yogyakarta includes determination of a street vendor's site and street vendors permit. The requirement of managing street vendors' sites are: do not obstruct the public interest; do not stand around government office buildings, a hero's grave, a monument, a tourist attraction and a place of worship. The street vendors site also has to consider the distance from the intersection of roads, the installation of electrical substations, gas \& petrol oil stations, at least 50 meters' distance.

Furthermore, there are rules about street vendors' equipment, such as buildings, tents or vehicles. The maximum size of those equipment is 4 meters long, 2 meters high. A street vendor's facilities/equipment must be disassembled and the site should be cleaned when operational time ends. There are three specified operational times: 02.00 am to 08.00 am (morning), at 08.00 am until $16.00 \mathrm{pm}$ (noon), 16.00 pm until 02.00 am (night). Each street vendor who does not meet these rules will be subject to administrative sanctions, such as: a written-statement warning, and license suspension. Each street vendor who has been carrying out its activities shall apply for a street vendor permit (license) maximum of 1 (one) year since the activity began.

Over time, the presence of street vendors in urban areas take some part of pedestrians/ street areas or public facilities, causing 
disruptions in social atmosphere, cleanliness of the environment, and disruption of traffic. It is necessary to have an arrangement in order to create a good social order incorporating both the community and vendor's involvement.

Rule violations committed by street vendors are mostly about sites or areas of their activities. Violation of rules relating to urban spatial structure, for example, street vendors occupying public space or state-owned land as site of their business. This condition causes disruption of traffic congestion, pollution, accumulation of waste/garbage and et cetera. Sidewalk and part of road (as a parking area) is the main violation of street vendors.

Here are some interviews with some of the street vendors who feel and know that he had broken a regulation, but remains in the site of his business.

"Actually I agree with the rule. However, I need a comfortable place to run my business, and there are no constraints if my business place will be relocated. In the past, we were often disciplined by municipal police officers. We followed the rules, but afterwards.... Back again, after the officer left. Other street vendors also did the same thing ... Well, the customers also liked the close site. So the customers also support us to stay here..."(DI01, interview dated October 23, 2015).

"I am aware of the risks. I occupy the sidewalk for my business. It is against the rules and harms pedestrians. I persevered because I think customers often come to my place. I once asked my customers what if I relocate? He was more than happy if I remained here. In addition, I was also responsible for any damage in this place, for example, I always maintain the cleanliness of the facility." (DI05, interview dated October 28, 2015).
Based on field observations, some disobediences committed by street vendors are as follows. 1) The street vendors occupied some public space, which put others as well as vendors in danger; 2) The presence of disorderly street vendors creates a messy urban space; 3) The existence of untidy street vendors is not in line with the vision of urban spatial structure that accentuates the aspect of beauty, cleanliness and tidiness of the city; and 4) Environmental pollution due to waste disposal.

Law enforcement officials stated that there are a lot of difficulties in implementing the rules. The difficulties are lack of support, both in terms of human resources and steps in implementing strict sanctions. Although the government often conduct surveillance by applying strict measures such as dismantling tents or street vendors' stalls, the availability of resources, both human resources and other social infrastructure, are not in line with the increasing number of street vendors and violations. The interview with one of the municipal police officer as follows.

"Demolition and dismantling stalls of street vendors who occupy the sidewalk in front of Prambanan subdistrict police station had to be done, because it has been deliberately breaking the rules, even though the vendors have promised to dismantle their stall. In accordance with the signed promissory note that the street vendors were willing to unload their stall by themselves on November 6, 2015, while up to 9, 2015 , were not yet dismantled, then the municipal police dismantled the stalls and took them to the municipal police office. Despite the stalls being dismantled and taken to the municipal police, street vendors could take back their stalls: tables, boxes and other equipment. Vendors can take them back in municipal police office, by showing their identification cards." (CI02, interview dated 10 November 2015). 
The above-described cases show that the street vendor's compliance to the rules are still low. Weak supervision and inconsistency in law enforcement by officers in charge contribute to the occurrence of repeated violations. This indicates that public trust in government to manage public facilities are also low. Socialization on the management of street vendors' sites and of regulations which contains rights and obligations of the street vendors is still less intensive.

\section{Discussion}

From the implementation of the two regulations: a) Law on Traffic and Road Transport and, b) local regulations on the street vendors' management described above, there are some lessons learned. There are several common aspects of compliance behavior to rules, both to road users and to street vendors. The citizens who did the offense agreed and supported the content of the rules, but they repeatedly broke the rules. There are several reasons underlying their inconsistencies. Not all citizens who committed violations were caused by lack of knowledge about the rules and dangers, but were caused by many factors. The most important one and also the most challenging which are imperative in restoring trust in government is reforming the behavior and mindsets of the people, both from the supply side and the demand side.

From the demand side, public trust depends on the intensity of the interaction as well as the quality of the relationship between the government and its citizens. As mentioned by See Beh (2013), trust in government as the reciprocity of expectations where the citizens expect that the government will perform in the interest of the citizens as they were promised. This implies from the data described above and also from other cases in many countries, that the government and officials are perceived as distant, corrupt and unaccountable, leading to a widespread crisis of legitimacy between citizens and the institutions that represent them. Hence, citizens' experiences of connecting with government institutions and officials has an effect on the process of forming trust in the institutions and officials. When citizens are in contact with a particular government institution, and then assess that government institutions and officials are helpful, open, and meet an easy access to information, the experience will shape their trust in the government. Furthermore, as the relationship between the government and its citizens becomes more interactive and participatory, citizens will become increasingly familiar with government activities. A more intensive relationship between citizens and government can build citizens' emotional attachment with government, official and policy. It is a crucial entry for building a good citizens' mindset about the government and its officials. This is in line with what Christense \& Laegreid (2013) stated, that citizens who have had positive experiences related to services provided by government institutions will have a high trust in those institutions.

On the contrary, from the supply side, when the government successfully meets the needs of its citizens, demonstrates its ability to efficiently and effectively implement its programs, and shows its concern for the problems faced by its citizens, such governments tend to enjoy high public trust. It is all about ensuring integrity. Ensuring integrity means that the behavior of civil servants in line with the public interest; reliably run public services; residents receive impartial treatment based on legality and justice. It can also be demonstrated through consistency in enforcing regulations, exemplary behavior of officers and commitment to always assist and resolve the problems of citizens. According to Ostrom and Walker (2003), in applying these general strategies, political leaders or government officials must understand that building trust takes time, and a series of 
repeated games needs to take place between the citizenry and the government before trust can flourish. Individuals, in other words, are more likely to trust one another after having interacted for several times together rather than on a first one-shot basis. In this case, citizens' involvement or participation in social and government activities become a strategic point. This is also in line with what Putnam (1993) said, that citizens' involvement and their trust in other citizens can shape political confidence. This interaction of citizens in social and governmental activities will not only make citizens have a higher trust towards other citizens but also build trust to government.

\section{Conclusion}

High public trust in government will facilitate government in implementing various policies, because the public believes that the government has a concern for the public interests and demands. Simply stated, to build public trust in government, the government must govern better. The shape of high or low public trust in government is manifested in public support through compliance behavior with the existing regulations or policies. Disobedience is a representation of government failure to realize the rule of law that is a reason why some of the processes and procedures of public services have not been followed or violated by people. The people's perception about bribes as part of the process to obtain public services still occurred, even though the government has been applying several systems and procedures that are open and transparent, and the information delivers symmetrically and is also easily accessible to the public. It can be concluded that the public trust in government policy implementation is the output of a variety of interrelated elements. The first element is the belief that the rule or policy is made to solve public problems or to reduce the burden of public affairs, which is viewed through the policy's performance. The second element is the consistency in the fairness of the enforcement of rules. The third element is public assessment of government officials' behavior, demonstrated through exemplary attitude.

Recommendations for the government and its apparatus can be generated in this study are as follows. First, improving public service performance. To get to that point, then conducting the assessment or evaluation of public services regulation should be done regularly in order to encourage the public services improvement, so that the dynamics of emerging public demands are aligned with the rule enforcement efforts. Moreover, citizens must also have the freedom to monitor and criticize what government does, and to voice their concerns. Second, establishing education and communication-based strategies by improving public information flow in the process of program implementation through various media channels, directly or indirectly. By helping citizens to obtain quality professional public services, which is applied based on the principle of accuracy and certainty of service, equality and fairness, slowly the public trust in the government will increase. Third, urging a consistent and effective rules enforcement in order not to cause prejudice to discrimination in the process of policy implementation and public service delivery.

Since this is a preliminary study, it implies some limitations. The result of this study is likely related to problem mapping of public trust primarily concerning the aspects of compliance, which essentially identifies noncompliance or violation as an expression of distrust in certain policies that regulate people's behavior. Therefore, future research may consider: first, expanding the coverage areas, as well as adding categories of respondents based on cases of public policies and services, using the survey technique, with a wider sample size; second, utilize other aspects related to factors such as pre-disposition demographic variables, as control variables to map the public trust 
issues in government, and: third, qualitative research techniques such as observation, interview, and even focus groups discussion are still proposed in order to obtain information that is complementary and comprehensive.

\section{References}

Baxter, P. \& Jack, S. (2008). Qualitative Case Study Methodology: Study Design and Implementation for Novice Researchers. The Qualitative Report, 13(4), 544-559.

Blind, Pery, K. (2006). Building Trust in Government in the Twenty-First Century: Review of Literature and Emerging Issues. Austria: The United Nations Department of Economic and Social Affairs.

BPS-Statistics of D.I. Yogyakarta Province. (2015). Yogyakarta Province 2015 in Figures. Yogyakarta, Indonesia.

Bouckaert, G. \& Van de Walle, S. (2003). "Comparing Measures of Citizen Trust and User Satisfaction as Indicators of 'Good Governance': Difficulties in Linking Trust and Satisfaction Indicators". International Review of Administrative Science, 69(3), 329-343.

Castillo, J.C., D Miranda, D \& Pablo Torres, P. (2011). Authoritarianism, Social Dominance and Trust in Public institution. Retrieved from http://mideuc.cl/wp-content/ uploads/2011/11/1107-castillo-mirandatorres-2011- trust-SDO-RWA-ISPP.pdf

Choudhury, E. (2008). “Trust in Administration: An Integrative Approach to Optimal Trust", Administration \& Society, 40(6), 586-620.

Christense, T. \& Laegreid, P. (2003). "Trust in Government - the Significance of Attitudes Towards Democracy, the Public Sector and Public Sector Reforms". Working paper. Retrieved from http://www.ub.uib.no/ elpub/rokkan/N/N07-03.pdf

Diamond, L. (2007). "Building Trust in Government by Improving Governance". Paper Presented to the 7th Global Forum on Reinventing Government: Building Trust in Government, June 27, 2007, Sponsored by the United Nations, Vienna.

Dwiyanto, A. (2011). Membangun Kepercayaan Publik melalui Reformasi Birokrasi. Jakarta: Gramedia Pustaka Utama.

Edelmen (The). (2017). The 2017 Edelman Trust Barometer: Global and Indonesia. Retrieved from https://edelman.id/trust2017/wpcontent/uploads/2017/02/2017-TrustBarometer_Indonesia_FINAL-VERSIONShare.pdf

Fukuyama, F. (1995) Trust: The Social Virtues and the Creation of Prosperity. New York: The Free Press.

Im, T., Cho, W., Porumbescu, G., \& Park, J. (2014). "Internet, trust in government, and citizen compliance". Journal of Public Administration Research and Theory, 24, 741-763, httpx://dx.doi.org/10.1093/ jopart/mus037

Kim, S-E. (2005). "The Role of Trust in the Modern Administrative State: An Integrative Model", Administration $\mathcal{E}$ Society, 37(5): 611-635.

Kleinnijenhuis, J., Anita M.J.van Hoof, \& Dirk Oegema. (2006) "Negative News and the Sleeper Effect of Distrust". Press/ Politics 11(2), 86-104, httpx://dx.doi. org/10.1177/1081180X06286417

Milgram, S. (1963). Behavioral study of obedience. Journal of Abnormal and Social Psychology, 67, 371-378

Montgomery, K., Jordens, C.F.C \& M. Little. (2008). "How Vulnerability and Trust Interact During Extreme Events: Insight 635 for Human Service Agencies and Organization". Administration and Society, 40(6), 621-44.

Nixon, D. (2007). The Role and Meaning of Trust in Institutions. Retrieved from http://www. trustlearningsolutions.com/wpincludes/ images/ValuesConference07.pdf

OECD. (2013). "Trust in Government", in Government at a Glance 2013. OECD 
Publishing. http://dx.doi.org/10.1787/ gov_glance-2013-7-en

Putnam, R. (1993). Making Democracy Work: Civic Traditions in Modern Italy. Princeton, N.J.: Princeton University Press.

Rawlins, B.L. (2008) “Measuring the relationship between organizational transparency and employee trust". Public Relations Journal, 2(2), 1-21.

Scholz, J. T., \& Lubell, M. (1998). “Trust and taxpaying: Testing the Heuristic Approach to Collective Action". American Journal of Political Science, 42, 398-417.

See Beh, L. (2013). "The Changing Face of Government: The Politics of Policy Change". International Journal of Policy Studies, 4(1), 105-13.

Tashakkori, A. \& C. Teddlie. (1998). Mixed Methodology: Combining Qualitative and
Quantitative Approach. London: Sage Publication.

Walker, R. M. (2011) “Globalized Public Management: An Interdisciplinary Design Science?" Journal of Public Administration Research and Theory. http://dx.doi.org/10.1093/jopart/muq064 Yin, R. K. (1994) Case Study Research: Design and Methods. Second Edition. London: Sage Publication. . (2003), Applications of Case Study Research. London: Sage Publication.

Zahroh, W. (2015). “Government Roles in Law Enforcement of the Implementation of Traffic Law". Unpublished Undergraduate Thesis. Yogyakarta: Department of Public Policy and Management, Universitas Gadjah Mada. 